From Hot War to Cold 



\title{
From HOT WAR to COLD
}

The U.S. Navy and National Security Affairs,

$$
\text { 1945-1955 }
$$

\author{
Jeffrey G. Barlow
}

Stanford University Press

Stanford, California 2009 


\section{Stanford University Press Stanford, California}

Editorial and design work

(C)2009 by the Board of Trustees of the Leland Stanford Junior University

\section{All rights reserved.}

No part of this printing may be reproduced or transmitted in any form or by any means, electronic or mechanical, including photocopying and recording, or in any information storage or retrieval system without the prior written permission of Stanford University Press.

Printed in the United States of America on acid-free, archival-quality paper

$$
\text { Library of Congress Cataloging-in-Publication Data }
$$

Barlow, Jeffrey G.

From hot war to cold : The U.S. Navy and national security affairs, 1945-1955 / Jeffrey G. Barlow

p. $\mathrm{cm}$.

Includes bibliographical references and index.

ISBN 0-978-8047-5666-2 (cloth : alk. paper)

1. United States. Navy-History-2oth century. 2. National securityUnited States-History-2oth century. 3. United States-Military policyDecision making. 4. Interservice rivalry (Armed Forces) - United StatesHistory. 5. Sea-power-United States-History-2oth century. 6. United States-History, Naval—2oth century. I. Title. 
To the naval officers of two U.S. Naval Academy Classes:

USNA Class of 1918-my grandfather Francis G. Barlow's Class (for most of Plebe Year)

and USNA Class of 1946-my father John F. Barlow's Class 
